\title{
Finite element modeling of folding during the superplastic forming of corrugated core panels
}

\author{
A. A. Kruglov ${ }^{1,2, \dagger}$, A. F. Karimova ${ }^{1}$, F. U. Enikeev ${ }^{1}$ \\ †alweld@go.ru \\ ${ }^{1}$ Ufa State Petroleum Technological University (USPTU), 1 Kosmonavtov st., Ufa, 450062, Russia \\ ${ }^{2}$ Institute for Metals Superplasticity Problems RAS, 39 Khalturin st., Ufa, 450001, Russia
}

\begin{abstract}
Corrugated core panels manufactured by methods of superplastic forming concurrent with diffusion bonding (SPF/DB) are promising for the production of high specific strength articles. One of serious problems arising in forming of corrugated core panels is concerned with the formation of outer folds. The cause of folding is uneven deformation of the skin sheets. In this study, the process of forming a corrugated core panel from a titanium alloy VT6 (analogue of Ti-6Al-4V) by computer simulation is considered. Finite element modeling is carried out using ANSYS software. The formulation of the boundary value problem is stated in terms of the theory of creep. It is shown that after completion of the formation of stiffening ribs, it is possible to increase the working pressure to a maximum without damaging the structure. The results of numerical simulation show that increasing the pressure and holding time allows one to eliminate folds. However, the pressure value is technically limited, and increasing the holding time reduces the economic efficiency of the process. It is noted that the process of forming a corrugated core panel has two characteristic stages. In the first stage, the core sheet is deformed under the conditions of superplasticity, stiffening ribs are formed. The first stage continues until the skin sections joined to the core touches the surface of the die. The second stage proceeds under conditions of creep up to smoothing the outer folds.
\end{abstract}

Keywords: superplastic forming, corrugated core panel, folding, finite element modeling.

УДК: $621.791 ; 539.374$

\section{Конечноэлементное моделирование складкообразования при сверхпластической формовке гофрированных панелей}

\author{
Круглов А.А. ${ }^{1,2, \dagger}$, Каримова А. $Ф .{ }^{1}$, Еникеев $Ф .{ }^{1}{ }^{1}$ \\ 'Уфимский государственный нефтяной технический университет, ул. Космонавтов, 1, Уфа, 450062, Россия \\ ${ }^{2}$ Институт проблем сверхпластичности металлов РАН, ул. Ст. Халтурина, 39, Уфа, 450001, Россия
}

Панели с гофрированным наполнителем в виде обшивок с внутренними ребрами жесткости, получаемые методами сверхпластической формовки совместно с диффузионной сваркой (СПФ/ДС), перспективны для изготовления изделий высокой удельной прочности. Одной из серьезных проблем формовки панелей с гофрированным наполнителем является образование наружных складок. Причиной складкообразования является неравномерная деформация обшивочных листов. В работе рассмотрен процесс формообразования гофрированной панели из титанового сплава ВТ6 (аналог Ti-6Al-4V) с помощью компьютерного моделирования. Конечно-элементная модель создана в среде программного комплекса ANSYS. Численная модель материала рассматривается в рамках теории ползучести. Показано, что после завершения образования ребер жесткости можно повысить величину рабочего давления до максимального значения без ущерба для конструкции. Результаты численного моделирования показали, что увеличение величины давления и времени выдержки способствует устранению складок. Однако величина давления ограничена технически, а увеличение времени выдержки снижает экономическую эффективность процесса. Отмечено, что процесс формовки панели с гофрированным наполнителем имеет две характерные стадии. На первой стадии лист наполнителя деформируется условиях сверхпластичности, формируются ребра жесткости. Первая стадия продолжается до момента контакта участками обшивок, соединенных с наполнителем, матрицы. Вторая стадия протекает в условиях ползучести материала конструкции до полного разглаживания наружных складок.

Ключевые слова: сверхпластическая формовка, гофрированная панель, складкообразование, конечно-элементное моделирование. 


\section{Introduction}

The corrugated core panel is one of the characteristic structures widely used in aircraft and aerospace vehicles. The combination of superplastic forming and diffusion bonding ( $\mathrm{SPF} / \mathrm{DB}$ process) is used to produce corrugated core panels. The corrugated structures are of a special interest when dealing with titanium alloys, first of all with Ti-6Al-4V. The initial blank of the corrugated structure is a sheet package consisting of three sheets: two outer sheets (skin sheets) and one inner sheet (core sheet). Diffusion bonding may be applied only to selected areas of a part by using a stop-off material that is placed between the sheets at locations where no bonding is desired. All three sheets are welded along their common perimeter. Superplastic forming is carried out by supplying an inert gas pressure inside sheet package. In the process of superplastic forming, the skin sheets take the form of a die, and the core sheet, stretching between the skin sheets, forms the stiffening ribs [1-3].

Since the skins are joined to the core only in certain areas, the deformation of the skins is uneven that may lead to the formation of folds on the outer surface of the skins $[4,5]$. One of the technological methods of eliminating folds is that the thickness of the skin sheets are chosen more than the thickness of the core sheet. Another method is concerned with reducing the angle of inclination of the stiffening ribs $[4,6,7]$. However increasing the thickness of the skins increases the weight of the article, and a decrease in the angle of inclination of the ribs lowers the stiffness of the structure that leads to a limitation of the design possibilities. An alternative way to provide the formation of structures without external folds is concerned with the selection of technological parameters of the SPF process. The use of modern methods of modeling appears to be useful in solving the problem of folding. The purpose of this work is to determine the limitations on the choice of technological parameters such as the pressure and holding time under pressure by means of usage of the finite element modeling.

\section{Modeling procedure and results}

Fig. 1 shows schematically a fragment of a corrugated core panel. The core sheet of thickness $s_{c}$ is placed between two skin sheets of thickness $s$. All three sheets are of commercial titanium alloy VT6 (Ti-6Al-4V). The pressure from inert gas is applied to the free surfaces of the inner cavities of the edge welded envelope. The height of the structure $\mathrm{H}$ is equal to the distance between the flat plates of the die. The angle between the ribs and the skin is denoted as $\varphi$. The temperature of SPF is equal to $900^{\circ} \mathrm{C}[1]$.

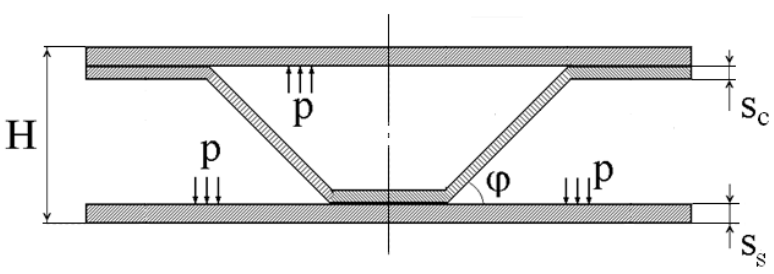

Fig. 1. Fragment of a corrugated core panel.
The following numerical data have been chosen for calculations: $s_{s}=0.8 \mathrm{~mm}, s_{c}=0.8 \mathrm{~mm}, H=10 \mathrm{~mm}, \varphi=35^{\circ}$. Computer modeling was carried out in a two-dimensional setting by using software ANSYS10.0 (ED). In view of the symmetry, only half of the fragment represented was considered. Finite element mesh is shown in Fig. 2.

The calculation area was divided into 381 PLANE82 elements with the Plane strain option. The tool was set as an absolutely rigid body using the TARGE169 element. The boundary conditions at the interface between the tool and the deformable body were set by the contact element CONTA172. The formulation of the boundary value problem has been set in terms of the creep theory using the Norton model, described in detail in [8]. Standard power law of superplastic flow has been included in the formulation of the boundary-value problem of creep theory as follows

$$
\sigma=K \xi^{m} \text { или } \xi=C \sigma^{n},
$$

where $\sigma$ is the flow stress, $\xi$ is the strain rate; $K, m, C, n$ are the material constants to be determined experimentally. The values of $K$ and $m$ have been chosen as follows [9]: $m=0.43$, $K=410 \mathrm{MPa} \cdot \mathrm{c}^{m}$. Since $C=1 / K^{n}$ и $n=1 / m$, then $n=1 / m=2.33$ and $C=1 / K^{n}=9.34 \cdot 10^{-21} \mathrm{~s}^{-1} \mathrm{~Pa}^{-n}$.

Pressure time cycle included two stages. At the initial stage, the pressure was increased from $0.1 \mathrm{MPa}$ to $2 \mathrm{MPa}$ for 300 seconds (Ramped mode). At the second stage, the exposure was held at constant pressure $p_{\max }$ (Stepped mode). The value of $p_{\max }$ was $2 \mathrm{MPa}$ and $4 \mathrm{MPa}$. The results of the simulation are collected in Table 1.

The selected modes of loading are determined by the following circumstance. As shown in [10] at an angle $\varphi$ up to $45^{\circ}$, the increase in pressure with SPF can be performed linearly. The rate of increase of the gas pressure is $6.67 \mathrm{kPa} / \mathrm{s}$, the value of $\xi<10^{-3} \mathrm{~s}^{-1}$. The value of $p_{\text {max }}$ corresponds to the modes [11]. The diagrams of the distribution of the first principal strain at the first stage of forming at $40 \mathrm{~s}$ and $300 \mathrm{~s}$ are shown in Fig. 3.

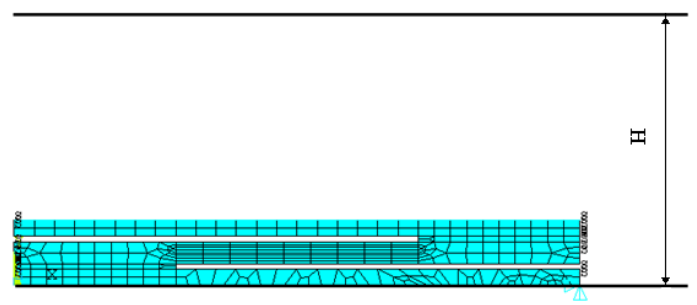

Fig. 2. Finite element mesh at the initial position.

Table 1. The results of finite element calculations.

\begin{tabular}{|c|c|c|c|}
\hline № & $\begin{array}{c}\text { Pressure }\left(p_{\max }\right), \\
\mathrm{MPa}\end{array}$ & Holding time, $\mathrm{s}$ & $\begin{array}{c}\text { Depth of the } \\
\text { groove, } \mathrm{mm}\end{array}$ \\
\hline 1 & 2 & 600 & 0.33 \\
\hline 2 & 2 & 1500 & 0.094 \\
\hline 3 & 2 & 3000 & 0.037 \\
\hline 4 & 4 & 600 & 0.063 \\
\hline 5 & 4 & 1500 & 0.017 \\
\hline 6 & 4 & 3000 & None \\
\hline
\end{tabular}


Fig. 4 shows the distribution of the first principal strain at the second stage of forming.

Fig. 3 illustrates how the skin sheets are deformed. First, the surface of the die is touched by the finite elements (FE) belonging to the free sections of the skin sheet (Fig. 3a). Then, the surfaces of the die touch the FE belonging to the skin areas are joined to the core sheet. The skin sheets become wavy. The crests of waves with increasing pressure assume a plane form of die. The soles of the waves fall on the joint of the skin sheets with stiffeners, which are formed from the core sheet (Fig. 3b). Namely, the soles of the waves become the place of formation of folds or grooves. As a rule, when the stiffeners are already formed, folds still occur on the surface of the skin. To eliminate folds, the pressure is increasing up to $p_{\max }$ and then maintains on this level. Fig. 4 and the results of calculations show that the higher the value of $p_{\max }$ the shorter is the time required for complete smoothing of the skin.

\section{Discussion}

Simulation shows that the process of forming the corrugated core panel has two stages. This confirms the conclusion of [4, $12,13]$ that at the first stage the stiffening ribs are formed. On the second stage, the skin sheets acquire the shape of the die and smoothing of the skin occurs. These stages are different in principle. The first stage proceeds under conditions of superplasticity while the second one under conditions of high temperature creep. From this it follows that the stages are different in the intervals of the strain rates of the material to be deformed. In practice it is worth to increase the value of the pressure up to $p_{\max }$ immediatedly after the completion of the initial stage of forming.
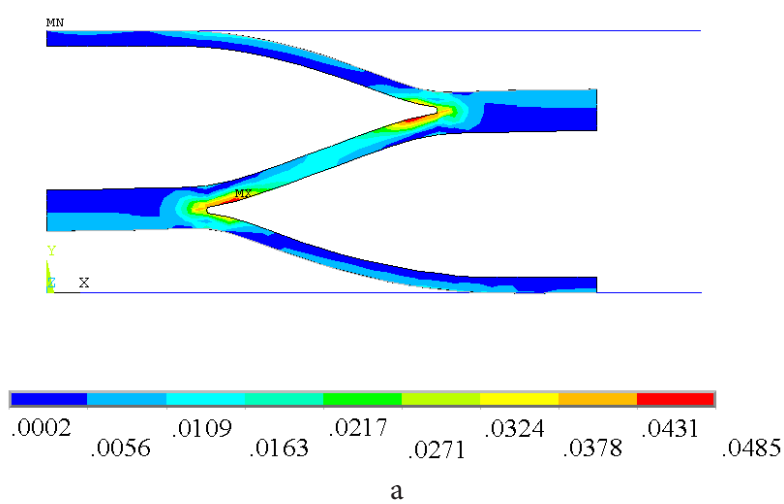

Fig. 3. (Color online) First principal creep strain at $40 \mathrm{~s}$ (a) and $300 \mathrm{~s}$ (b).
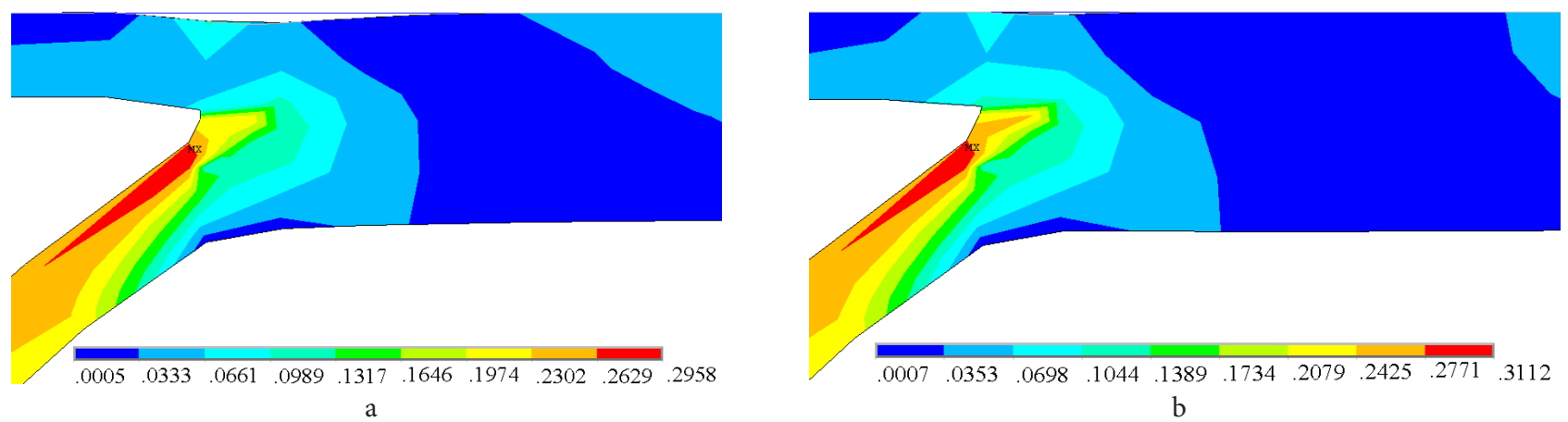

Fig. 4. (Color online) The distribution of the first principal strain at a holding time of $1500 \mathrm{~s}$ and $p_{\max }=2 \mathrm{MPa}(\mathrm{a})$ and $p_{\max }=4 \mathrm{MPa}(\mathrm{b})$. 
Aknowledgements. The present work was accomplished according to the state assignment of IMSP RAS No. AAAA-A17-117041310221-5.

\section{References}

1. Superplastic Forming of Structural Alloys: Proceedings of a symposium. Eds. N.E. Paton, C.H. Hamilton. Warrendale, PA, TMS-AIME (1982) 414 p.

2. W.D. Brewer, R. K. Bird, T. A. Wallace. Materials Science and Engineering. A243, 299 (1998).

3. J.D. Beal, R. Boyer, D. Sanders. In: ASM Handbook, Volume 14B, Metalworking: Sheet Forming. Ed. S.L. Semiatin. Materials Park, Ohio, ASM International (2006) 908 p. Forming of Titanium and Titanium Alloys. pp. 656 - 669. DOI: 10.1361/asmhba0005146

4. J.-Ho Cheng, S. Lee. J. Mater. Process. Technol. 45, 249 (1994).

5. E. Chumachenko, O. Smirnov, M. Tsepin. Superplasticity: materials, theory, technology. Moscow, Librokom (2009) 320 p. (in Russian) [Чумаченко Е.Н., Смирнов О.М., Цепин М.А. Сверхпластичность: материалы, теория, технологии. Москва, Либроком (2009) 320с.] ISBN 5-484-00005-X
6. A. Akhunova, S. Dmitriev, A. Kruglov, R. Safiullin. Deformatsiya i Razrushenie Materialov. 11, 41 (2012). (in Russian) [Ахунова А. Х., Дмитриев С. В., Круглов А. А., Сафиуллин Р. В. Деформация и разрушение материалов. 11, 41 (2012).]

7. J. Shao, Z.Q. Li, H. Xu, X. Han, R. Zhang. Materials Science Forum. 838-839, 585 (2016).

8. F. U. Enikeev. Russian Journal of Non-Ferrous Metals. 49(1), 41 (2008). DOI: 10.3103/S1067821208010082

9. F. U. Enikeev, A.A. Kruglov. International Journal of Mechanical Sciences. 37(5), 483 (1995).

10. A.A. Kruglov, A.Yu. Samoilova, A.A. Slesareva, O.P. Tulupova, F. U. Enikeev. Letters on Materials. 4(1), 72 (2014). (in Russian) [Круглов A.A., Самойлова А.Ю., Слесарева А.А., Тулупова О.П., Еникеев Ф.У. Письма о материалах. 4(1), 72 (2014).] DOI: $10.22226 / 2410-3535-2014-1-72-75$

11. Patent EP № 0568201, 01.04.1993.

12. A. Akhunova, S. Dmitriev, A. Kruglov, R. Safiullin. Adv. Mater. 12, 44 (2011). (in Russian) [Ахунова A.X., Дмитриев С.В., Круглов А.А., Сафиуллин Р.В. Перспективные материалы. 12, 44 (2011).]

13. P. Anderson. Materials Science Forum. 838-839, 621 (2016). 